\title{
INTERNATIONAL FIELD PRACTICE (PPL): PROBLEMS, IMPLEMENTATION, AND COMMUNITY RESPONSES
}

\author{
Hani Hartiani Kurnia Putri ${ }^{1)}$, Dewi Putri Nabila ${ }^{2)}$, Andang Saehu ${ }^{3)}$, Irman Nurhapitudin ${ }^{4)}$. \\ ${ }^{1)}$ English Literature, Humanity Faculty, Islamic State University Sunan Gunung Djati Bandung, e-mail: \\ hanihartiani157@gmail.com \\ 2) English Literature, Humanity Faculty, Islamic State University Sunan Gunung Djati Bandung, e-mail: \\ dputrinabila@gmail.com \\ ${ }^{3)}$ English Literature, Humanity Faculty, Islamic State University Sunan Gunung Djati Bandung, e-mail: \\ andangsaehu@uinsgd.ac.id \\ 4) English Literature, Humanity Faculty, Islamic State University Sunan Gunung Djati Bandung, e-mail: \\ irmannd@gmail.com
}

\begin{abstract}
This paper is an evaluative study to explore and analyze the process of implementing the International PPL, the problems encountered in the implementation of International PPL, and the community responses to the implementation of International PPL. In working with the implementation, International PPL was conducted in three steps: pre-field research activities, whilst field research activities, and post-field research activities. Some internal and external problems faced in the implementation of this International PPL. The responses to the International PPL implementation were gained from both internal and external communities.
\end{abstract}

Key Words: Community Response, Field Research, Implementation, International PPL, Problem.

\section{INTRODUCTION}

Field Practice (PPL) program is as a part of the curriculum in the English Literature Department, Faculty of Humanities, State Islamic University of Sunan Gunung Djati Bandung. This program is routinely implemented by $6^{\text {th }}$-semester students but currently, it is deserved to the $4^{\text {th }}$-semester students. The implementation is at the end of $4^{\text {th }}$ semesters, exactly at break time to $5^{\text {th }}$ semesters around July or August. Awaludin, the Chairperson of English Literature department, announced in the opening ceremony of PPL that it is to be implemented around July or August, which is a semester break time, to make the time more efficient and more useful.

PPL is one academic activity that promotes and combines education and co-curricular activities for students. English Literature department conducts this International PPL as a life screening, borrowing a term proposed by Prensky (2001), to prepare the students for a life of civic engagement and a sense of social responsibility as well as a global citizenship, to enhance their career development by connecting educational goals with service to those in need (Twelvetrees, 1991), and to engage with the community outside the classroom (Saehu \& Nugraha, 2019). The department enforces a field practice that is aware and respectful of the diverse realities that surround us. International PPL is conducted to: introduce the students the real world outside of Indonesia; experience the real-life and communication with people outside of Indonesia; and apply what they have learned in the campus in terms of creative writing, travel writing, and research.

The implementation of this International PPL is hardly easy. There are many challenges and problems faced by students who are involved in this PPL starting from the pre-implementation to the postimplementation. Even, its implementation is considered different from the previous International PPLs. Of the problems faced and International PPL experienced, we are also curious to know the responses to the PPL conducted in Malaysia. Therefore, some questions are addressed in this paper in light of the aforementioned background.

The problems to be addressed are: 
1) What problems are faced in the implementation of International PPL?

2) How is the implementation of PPL International?

3) What is the community responses to the implementation of PPL?

\section{METHOD}

This paper is an evaluative study. The main aim is to evaluate the implementation of a work program, namely International PPL. But this is not limited to only evaluate the implementation but also to evaluate the obstacles or problems faced during the implementation of International PPL. This is in line with Sururie, et al. (2019) stating that evaluation is needed to see the effectiveness of a program and identify the obstacles that occur. Evaluation is needed to see whether a program is effective and well-targeted so that it is possible to make improvements or adaptations to the implementation of the program in the future. This evaluative study is needed to be conducted in order to see whether its implementation should be aborted, modified, or continued for future implementation.

The implementation of International PPL is evaluated by ways of looking at the output of its implementation and responses given by the community, even from the impact on students, department, faculty and the university.

\section{DISCUSSION}

The English Literature Undergraduate Program of the Adab and Humanities Faculty of Sunan Gunung Djati State Islamic University Bandung is one of the institutions of higher education that has a special purpose, namely to produce qualified scholars, as skilled experts and ready to use in their fields and able to adapt themselves to the changing times and community needs in creating opportunities for the development of science and technology and industry 4.0.

English Literature is a scientific discipline that was created thanks to the ability of human abstraction as a natural creature. Nowadays language and literature are increasingly important to keep pace with the advancing era (Novianti, 2016).

In addition to the aforementioned student activities outside the campus to increase knowledge about the field of study is a positive activity that must continue to be encouraged. In line with the times that have experienced an expansion of opportunities, student activities off-campus are in the form of field studies or field observations. This coincides with
Billet (2010) stating that the woot of contributions from practice settings and experiences are a growing knowledge and interest in learning through life.

For this reason, graduates of the English Literature Study Program at Faculty of Humanities, Sunan Gunung Djati State Islamic University in Bandung are expected to have competencies according to the curriculum, namely language analysts, literary analysts, beginner translators and able to apply them in the modern world (Buku Pedoman Akademik, 2017). Mastery of curriculum competencies is obtained through lecture procedures, while its application can be enriched through PPL.

Therefore, the students of the English Study Program of the Humanities Faculty of Sunan Gunung Djati State Islamic University Bandung attract to do field research in the form of International PPL to Malaysia. However, there are some problems encountered in the implementation of PPL to Malaysia.

\section{Problems Encountered in the Implementation of International PPL}

International PPL is inseparable from the challenges and problems. These include internal and external and problems.

\section{Internal Problems}

Internally, International PPL faces its own challenges in its implementation, both at the level of the department, the deanery of the faculty of humanities, and participants.

First, the problems coming from the Department was identified in the meeting between the Chairperson team of English Literature department and students of the same department conducted on TGL BERAPA (When)? The chairman mentioned nothing about the International PPL at that time. As students. we were curious to find the specific reasons for omitting the International PPL in this year. The reasons were provided by the Chairperson that the department is worried about the safety as the department and the faculty cannot give any insurance and guarantee to the participants' safety. They also said that no budget provided by the department and faculty for International PPL. Further, they said that International PPL seemed not to have a significant contribution to the department and faculty. The final remark of them said that but, if you are eager to 
implement the International PPL, please convince us the model and output of the implementation.

Knowing those reason which sounded challenging for the students, we were then curious to know some facts about the reasons. Some of the students who were willing to join the International PPL wrote an International PPL implementation proposal to the department and deanery. Within the proposal, we convince them that the safety aspect is not the sake of the human. It is the only Allah can protect every human life. Indeed, for the implementation of International PPL safety, we are sure that the department will provide us supervisors that guide us to do something well.

Regarding the budget, we did some comparative studies to English Education department of Faculty of Teacher Training and Education of UIN Sunan Gunung Djati Bandung and to students of Tulung Agung, East Java. Their statements showed the same wavelength that the students participated in the International PPL paid themselves pursuant to the amount decided by the Department. So, this should not be a kind of problem that must be a burden of the department (Sajidin, et al., 2018).

In relation to the significance of International PPL, we did some interviews with the Chairperson of the English Education department and one of the lecturers. The Chairperson said that when the university was in the process of increasing an addedvalue of accreditation, they asked him to send some documents of Memorandum of Understanding and photos relating to the International PPL. Even, we also checked the form or borang of accreditation of English Literature department and we found inside that the activity of International PPL is listed inside. It is listed due to the consideration that the International PPL is an extraordinary program that only English departments can do it in Sunan Gunung Djati State Islamic University. If it is not significantly contributed to the university, faculty, and department, why they asked for the evidence to the Chairperson of the English Education department.

Within the proposal, we also convinced them that the current International PPL has a model, namely doing field research in Malaysia. The methods of collecting data we used are observation and interview. The observation is done to the destinations we are going to visit. While doing the observation, we also would like to interview some foreigner tourists knowing their perceptions and intentions to visit the destinations. Through this model and perhaps other considerations, the
Chairperson of the English Literature department allows us to do field research in Malaysia.

The problem was also coming from the Deanery of Faculty of Humanities, Sunan Gunung Djati State Islamic University. As the allowance from the Department has not been shared yet to the deanery, the Dean did not allow us to do because there was no official statement from the Chairperson of the department. Other reasons were the same as mentioned by the department in terms of safety and budget. But finally, the Dean also allowed us to do field research after having an official letter of allowance from the department.

Another problem was coming from the participants after being allowed to do International PPL by the department and faculty. The problem was started from the process of passport application. Some of us went to immigration offices directly to apply for the passport, but then it should be done through the immigration website. The fact, it was not easy to do online application as the dates were fully booked by other consumers. It affects the dates we have set to do field research in Malaysia. Therefore, we needed to reschedule the dates of departure when the passports were completely issued. The next problems the participants experienced was about flight and hotel booking. Since the fund of International PPL was genuinely provided by the participants, we tried to find the budgeted flight and hotel. It was hardly easy to find suitable budgets. The fact that on the first night we checked in to the hotel that most of the participants complained about the comfortability.

Besides that, due to the lack of experiences of the participants to go abroad, the participants were assisted by the supervisors assigned by the Department to guide us on what to do. The supervisors directed us to make a committee with different job descriptions, consisting of the Head, the Secretary, the Treasurer, and Public Relations. The supervisors also directed us to find the destinations to be visited in order to be immediately confirmed by them. Everything we did was under the guidance and consideration of the experienced supervisors.

As mentioned before that the problems are not only coming from the internal aspect but also from the external aspect.

\section{External Problems}

The external problem we found was only about the lack of foreign tourists' involvement during the implementation of International PPL. We realized that it was about $40 \%$ of participants did an interview with the foreign tourist. Dominantly the data were 
taken from the local tourists, like Malay, Chinese and Indians. Each of whom has been living in Malaysia for a long time, even the nationality of Chinese and Indian have been legalized as Malaysian people. Their lack involvement was due to the consideration that the cover letter of research was limited only for data existing in Embassy of Republic of Indonesia for Malaysia (KBRI), National University of Malaysia (UKM), University of Malaya (UM), and Museums. So, when the tourists asked me to show the cover letter and we couldn't fulfill it, the interview was neglected by them. We do understand their ways of asking the cover letter as they felt uncomfortable. Luckily, some of us could take the data by interviewing the foreign tourists.

\section{The Implementation of International PPL}

International PPL was held for 5 days, starting from August 19 to 23, 2019 in Malaysia, precisely in Kuala Lumpur. The program was attended by 36 students and 2 supervisors, namely Drs. Irman Nurhapituddin, M. Hum and Dr. Andang Saehu M.Pd. This PPL was conducted in three steps, namely Pre-Field Research Activities, Whilst Field Research Activities, and PostField Research Activities.

\section{Pre-Field Research Activities}

There were some activities we did in the step, namely Licensing, Survey, Passport Application, Consultation and Training, the licensing is the attempts we did to obtain official allowance provided by the English Literature department and the faculty of humanities. Having a passport is of utmost importance for everyone before going abroad. Therefore, we applied for the passport to the immigration offices. The survey is a kind of transect which was not really coming to the countries we are going to be an object of the PPL. It was conducted by asking the previous supervisors' experiences in guiding the students to Singapore, Malaysia, and Thailand. Having gained sufficient information about the selected country, we proposed it to the department and the faculty.

Then we did consultation and training with the supervisors assigned by the department. The consultation was about the destinations to be the objects of the field research. The result of the consultation showed that there were some places to be visited. Each of which was 4 academic destinations, consisting of KBRI, UKM, UM and Museum and 11 leading tourist destinations, including Genting Highland, Batu Caves, Petronas Twin Tower, Daratan Merdeka, Putrajaya, State
Palace, Sungei Wang, National Monument, Chinatown, Central Market, and Bukit Bintang.

The implementation of this activity began when students and supervisors gathered in front of the UIN Sunan Gunung Djati Bandung Rectorate building at around 23:00 pm to talk about collecting International PPL reports while waiting for a bus that would take the participants to Soekarno Hatta Airport. The meeting concluded that the collection of reports would be limited to 2 weeks after returning from Malaysia. The decision was taken after considering the estimated time that would be needed for editing until finally it would be sent to the publisher to become an ISBN book.

International PPL participants finally left for Soekarno Hatta Airport at 01.30 am and arrived at $08.00 \mathrm{am}$. Regarding the technicalities of departure, participants were divided into 3 groups that had different departure schedules. The first group departs at $11.00 \mathrm{am}$, the second group departs at $14.00 \mathrm{pm}$ and the last group departs at $14.50 \mathrm{am}$. Distribution of this departure schedule can not be avoided because bookings are made manually through the online ticket booking application. The method was chosen because it considers the price of tickets that are not stable at the time.

After going through air travel for about 2 hours, all International PPL participants finally gathered at Kuala Lumpur International Airport at $17.00 \mathrm{pm}$ Malaysian time. Then at $19.30 \mathrm{pm}$, the participants were picked up by a bassist who would take the participants to the hotel to rest. While PPL activities will start the next day starting at $09.00 \mathrm{am}$ Malaysian time.

The journey of the International PPL participants opened with a visit to 2 leading universities in Malaysia, namely the University of Malaya (UM) and Universiti Kebangsaan Malaysia (UKM). But the participants of the PPL could not hold a seminar at UM or UKM because the department had blocked it. So, in the end, the seminar could only be conducted at the Indonesian Embassy.

The training was provided by the supervisors focusing on travel writing, journal submission, mass media writing, and book chapter writing. In other words, the training was demanded to be pursuant to the output of the International PPL. The output consists of journal submission, anthology book publication, and travel writing report.

\section{Whilst-Field Research Activities}

The activities included in this step are Departure, Immigration Check-In, Arrival, Briefing, and Field Research. The first three activities (departure, 
immigration check-in, and arrival) will be simultaneously analyzed at they could not be separated from each other.

In relation to departure, it was started on August 19, 2019, from the rectorate building of UIN Bandung to Soekarno-Hatta International Airport (SHIA) by using a travel bus. Then all the participants must check-in their passport in immigration for twice. Each of which was in and in Kuala Lumpur International Airport (KLIA). The process of checking in the passport was running well, such as getting boarding pass, registering suitcases for baggage, fingerprinting while being interviewed by the immigration officers, and checking our bags and luggage whether we bring prohibited kinds of stuff, like alcohol, knife, power bank with more than $20.000 \mathrm{mAh}$, etc. or not.

It spent around 2 hours to arrive at the KLIA. We did the same procedures as done in that of the SHIA immigration, starting from boarding pass to taking our suitcases from the baggage. At the arrival gate, a travel bus under Malaysian management has been waiting for one hour there then dropping us in the hotel.

The next activity we did was briefing between the participants and the supervisors. The briefing is a short meeting among the parties (Nea, 2010). This activity was regularly conducted every day before leaving the hotel and after coming back to the hotel. In the first day of the briefing, the supervisors directed us, especially the participants assigned to take the data in the places they are going to visit. The first-day visits were KBRI, UKM, UM, and Textile Museum. The supervisors emphasized us in terms of keeping good behavior and attitude wherever we are. The meetings in the first three places were more academic.

The process of taking data was begun by welcoming remarks from the team of KBRI, UKM, UM, and from the supervisors. Question and Answer sessions between the representatives of those three institutions and the PPL participants were the ways of collecting the data focusing on the roles of KBRI in Malaysia, the curriculum used in UKM and UM, the conditions of Indonesian people in Malaysia in case of being students or employers.

The next day briefing was about the reflection of the first day activities and the guidance for the next day activities. The supervisors asked the participants to report orally to what they have experienced on the first day. The supervisors then asked the committee about who were going to take the data in the next day. Those assigned to collect data in the non-academic destinations were asked to find the information about the destinations and write some questions about them. The answers to those questions must be taken through an interview from the informants-local tourists, foreign tourists, and indigenous people. Take a look at the figure showing the process of interview below.

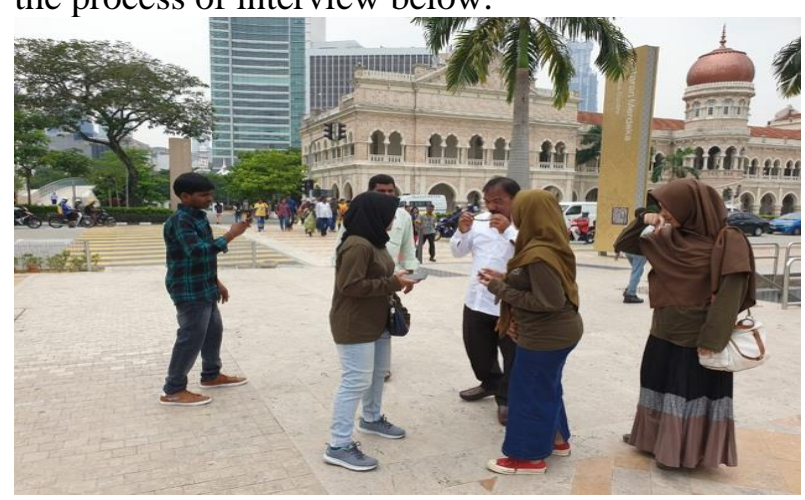

Figure 1. The Interview with Indian Tourists

The next briefing was done on the third day. The focus of the briefing was on the evaluation of the field research. After listening to the reports from the assigned participants, the supervisors gave some comments, feedback, and revisions to be increased in the next day. According to Hattie \& Timperley (2007), feedback is one the most powerful influence on the program achievement.

\section{Post-Field Research Activities}

Having conducted the field research in Kuala Lumpur, Malaysia, all participants require to do some activities, namely writing a report, disseminating the report, and presenting the report.

The reports of the field research were done pursuant to the expected outcome. The participants require to publish an anthology book with ISBN from a popular publisher. Fortunately, a book has been published under the title "Let's Do Field Research in Kuala Lumpur." Within the book, there are 36 field research reports written by 36 students participating in International PPL. The following is the book.

Besides, the participants were also demanded to disseminate the field research report into the journal and some mass media. In relation to mass media, there were 27 electronic mass media that shared the information about the implementation of International PPL. This is a great achievement for us, the participants because automatically we introduce our beloved university to the world. This is believed that this kind of dissemination can be one 
of the attempts to help the university make the vision comes true.

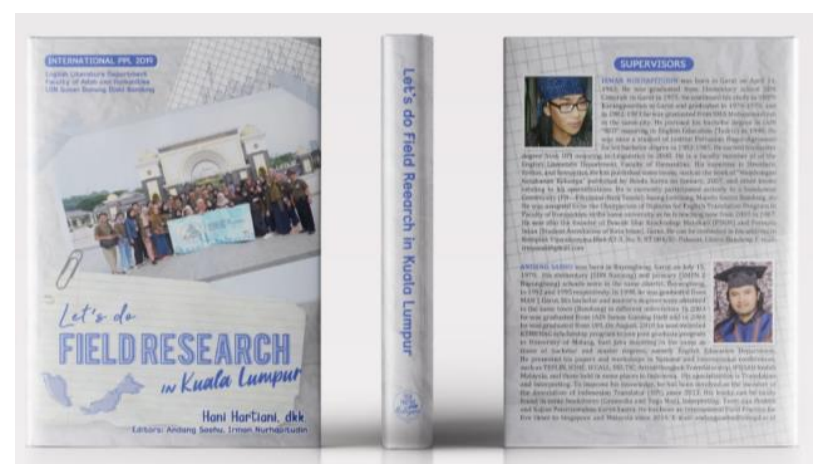

Figure 2. An Anthology Book of Field Research

The participants also required to report orally in the form of presentation in front of the students. Even, when someday, there is a seminar both national or international level, we under the supervisors' guidance would like to present the field research report. Take a look at the following figure.

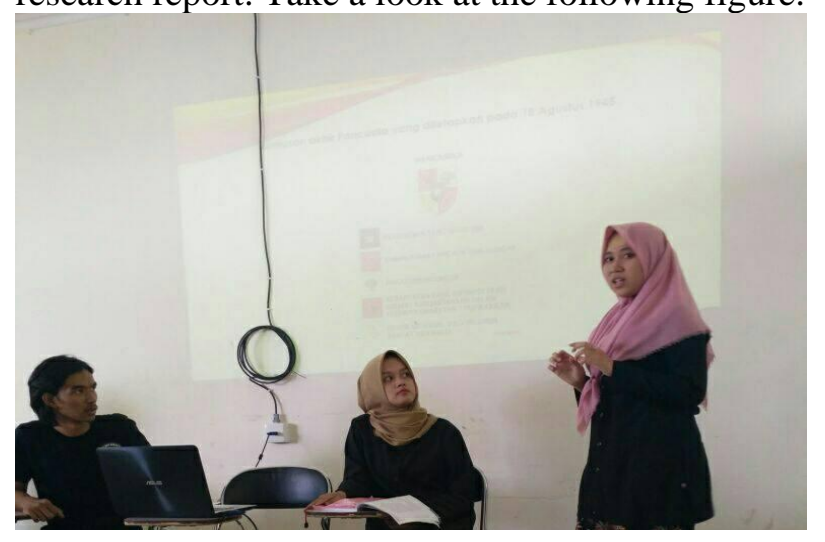

Figure 3. Presenting the Field Research Report

\section{The Community Responses to the Implementation of International PPL}

As part of the evaluation, this paper raised the question about the responses from the community to the implementation of the International PPL. The data was gained through an interview with the Chairperson of English Literature department, the lecturers, and the non-participant students. The responses were also obtained from those reading the report in mass media through online interview.

The International PPL received positive and negative responses from the community. Interviewing with the department showed two responses: the first, the department do appreciate the creativity of the participants, the supervisors' involvement and guidance, and the attainment of field research outputs. The second, the department feel something like losing contact with the International PPL team as, during the taking data in the field research, there was no updated information about what we were doing. The department commented that we should create a blog informing our activities during the field research in order to be monitored easily.

As soon as the International PPL activity was completed, various mass media began to pay attention to the success of this program. In total there are about 27 electronic mass media that raise news about the International PPL organized by English Literature department students of UIN Sunan Gunung Djati. Media which published this news, to mention some, included Intronews, Balebandung, Klikwarta, Exposure, Dejabar, People's Dialogue, 86news, West Java Media, Education, Kemenag.go.id, Moeslimchoice, Ikhlas Beramal News, uinsgd.ac.id, a news media on Instagram, etc.

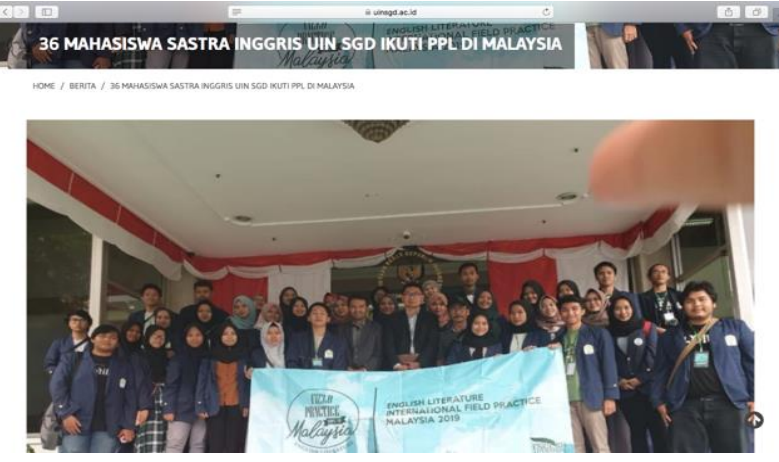

Figure 4. Mass media reporting International PPL

The large number of mass media that responded positively to this field research raised the responses from the lecturers around the campus. They asked some questions relating to the procedures, the fund, the itinerary, and so on. Those kinds of questions were considered a positive response to the implementation of International PPL. This can be proven by the many positive responses and greetings given to the supervisors, committee, and participants of this International PPL.

International PPL became one of the media for students of UIN Sunan Gunung Djati Bandung, especially in English Language and Literature majors to expand knowledge in the field of language and culture in the international field.

The success of the International PPL program is like a strong whip for those who had initially negative responses to the process of the 
implementation of this program. One thing that needs to be realized is this activity was actually able to open students' insights about the outside world, both in terms of language and culture, as well as learning about the advantages of other countries, which might be applicable in Indonesia. For this reason, this program should be able to get more support from the campus and serve as one of the flagship programs, especially in the English Language and Literature department of UIN Sunan Gunung Djati Bandung. International PPL opens the way for students of UIN Sunan Gunung Djati Bandung to be able to hold an International Community Service Program.

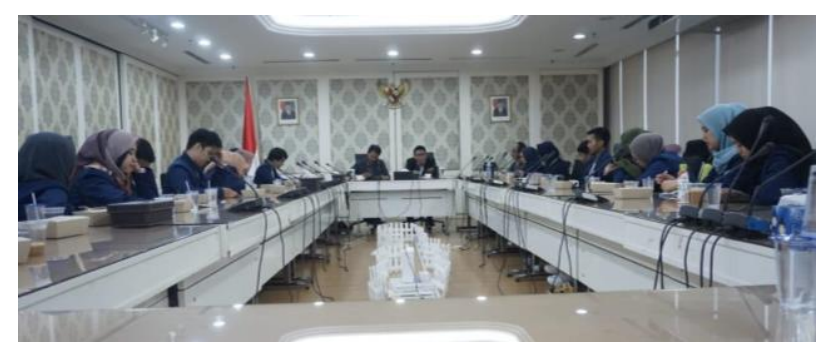

Figure 5. Interview with KBRI for Malaysia

Figure 5 shows that the positive response was also provided by Mr. Erwinsyah, the Deputy of Education and Culture Affairs of KBRI for Malaysia. He said that this kind of activity can open our mind, broaden our insight, and push our motivation to be the best person. He also challenges the supervisors to talk to the leaders' concern in Community Service, as one of the Tridarma, to propose a program that can help Indonesian people living in urban areas, such as those living in Sarawak and Sabah.

International PPL gives a very deep impression to the participants who take part in this program, both in terms of the knowledge gained, and in terms of friendship. Although initially PPL participants came from different classes and did not know each other, in the end, the participants were able to get to know each other and make friends. Even indirectly, this program is also able to foster a sense of mutual care among students who take part in this program. In addition, the obstacles encountered during the preparation process of this program can instead be used as a life lesson. Because basically to achieve success requires a struggle and a very strong determination. Because if only at that time the supervisors, committee, and PPL participants surrendered, then this program might never have been carried out

\section{Acknowledgment}

Thank you very much to the honorable Dean of Humanities Faculty and the Chairperson of the English Literature department who finally allowed us to implement the International PPL. This was a great lesson for us to become an independent person.

Our deepest gratitude goes to the supervisors namely Drs. Irman Nurhapitudin, M.Hum, and Dr. Andang Saehu, M.Pd who always motivate and guide us so that we will never give up to keep on actualizing this International PPL. Also, thank you very much to parents who have supported and allowed us your children to join the International PPL so that we can implement this PPL well.

Finally, for my strong partners who are always compact in the process of actualizing this International PPL, we go through hurdles together even though sometimes we often disagree, we are still together. In the end, we successfully implemented this PPL, it was proven that we could establish relations with the Indonesian Embassy in Kuala Lumpur to make good news for department, faculty, and university. We are able to carve good things for us and others. Thank you to all of you, the greatest partners and love you.

\section{CONCLUSION AND SUGGESTION}

\section{Conclusion}

The International PPL is one of the PPL (field practice) programs from the English Literature department, which in the preparation process has been faced with many problems, both externally and internally, such as difficulties in obtaining permits from the campus, obstacles in booking airplane tickets, lack of budget, even to the problem of participants' passports being made late. However, these problems can eventually be resolved properly, so as not to interfere with the smooth implementation of this International PPL. The International PPL program is well implemented indirectly whipping for those who initially did not support, even oppose the existence of this program. Although initially there were many negative assumptions which assumed that PPL International was only a recreation. But in reality, this program is one way to open students' 
insights about the diversity of languages and cultures throughout the world. Then the results of these observations can be poured in the form of written works, such as books, journals, travel reports and many more. But then finally the responses from the community to the implementation of International PPL was dominantly positive.

\section{Suggestion}

The problems that occur during the preparation process of International PPL are proof that the campus does not support student activities. The campus is considered too pessimistic and cannot be confident when running an international-based program. It would be better if the campus at least did not complicate the process of organizing this International PPL program in the following years. Judging from the impact of this PPL it is very good, can establish relationships with the Indonesian Embassy in Malaysia and get a good response from various parties.

\section{REFERENCE}

Billet, S. 2010. Learning through Practice: Models, Traditions, Orientations, and Approaches. Australia: Griffith University.

Hattie, J., and Timperly, H. 2007. The power of feedback. Journal of Review of Educational Research, Vol 77(1), 81112.

Novianti, N. 2016. English Literature Teaching: An Indonesian Context. Indonesian Journal of Applied Linguistics, Vol.6(1), 42-49.

Nea, B. 2010. Briefing: The Importance of Teaching. London: ROTA.

Prensky, M. 2001. 'Digital Natives, Digital Immigrants', On The Horizon (9) 5.

Saehu, A., \& Nugraha, F. 2019. KKN Sisdamas: Optimalisasi Pemberdayaan Masyarakat melalui Smartphone. A report submitted to LP2M. Bandung UIN Sunan Gunung Djati.
Sajidin, Saehu. A., Sulaeman, A. 2018. Model Pelaksanaan PPL Internasional bagi Mahasiswa Calon Guru di Lingkungan PTAIN. Bandung: UINS Sunan Gunung Djati.

Sururie, R.W., Aziz, R., Uriawan, W., Zulqiah., Mardiansyah, Y., \& Fridayanti. 2019. Model KKN Sisdamas UIN Sunan Gunung Djati Bandung: Tantangan dan Peluang Pelaksanaan. Alkhidmat: Jurnal Ilmiah Pengabdian kepada Masyarakat, Vol2(1), 23-27 .

Twelvetrees, A. 1991. Social Planning Approaches to Community Work. In: Community Work. Practical Social Work. London: Palgrave. 